\title{
2 The life of people
}

\section{Introduction}

The European Bronze Age world was abundantly peopled (Fig. 2.1). We do not know exactly how many people there were across the continent (though we can make estimates), nor do we know the name of anyone who lived at that time - outside the Aegean world, where the Linear B documents name various individuals and occupations. But we can see from depictions and burial finds that Bronze Age people looked like us, more or less, carried out many of the things we do, such as securing food, clothing and shelter, and no doubt thought and felt many of the same things we do - emotions, rational thinking, planning - as well as many irrational things which we find it hard to explain.

The first task I set myself, then, is to talk about people: the people who inhabited Europe in the period between the mid-third millennium BC and the earlier first millennium BC, a period of almost 2000 years. Who were these people? Did they form a homogeneous ethnic unit, or were they, like today's Europeans, a mixture of many different backgrounds? Did they speak one language or many? How numerous were they? Did they live long and healthy lives, or - more likely short and disease-ridden ones by present-day standards? How did they regard themselves and each other? Their social relations are of course also of great interest, though I shall say more about that in a later chapter. In short, who were the people who occupied the continent we call Europe, and who must have formed the basis on which the classical civilisations of Greece and Rome, along with their barbarian neighbours, were founded?

A great deal has changed over the course of my career in terms of discoveries and techniques, and the ways in which we view them. In terms of finds, I maintain that the revolution started in 1981 with the discovery of the Uluburun shipwreck, without doubt one of the most important and astonishing finds from the later prehistory of the Old World ever made (most fully accessible in Yalçin et al. 2005). The finding of Ötzi the Iceman in 1991 was also extraordinary, but he belongs to the Copper Age rather than the Bronze Age, a thousand or more years before the period I am concerned with here. A year later a Bronze Age boat was found in Dover (Clark 2004), and around the same time, beads of amber of Italian type from the kurgans at Hordiivka in Ukraine (Berezanskaja \& Kločko 1998); and gold cups similar to those long known from Fritzdorf and Rillaton were found in Kent, south-east England (Ringlemere) (Needham et al. 2006), joined most recently by a somewhat similar piece from northern 

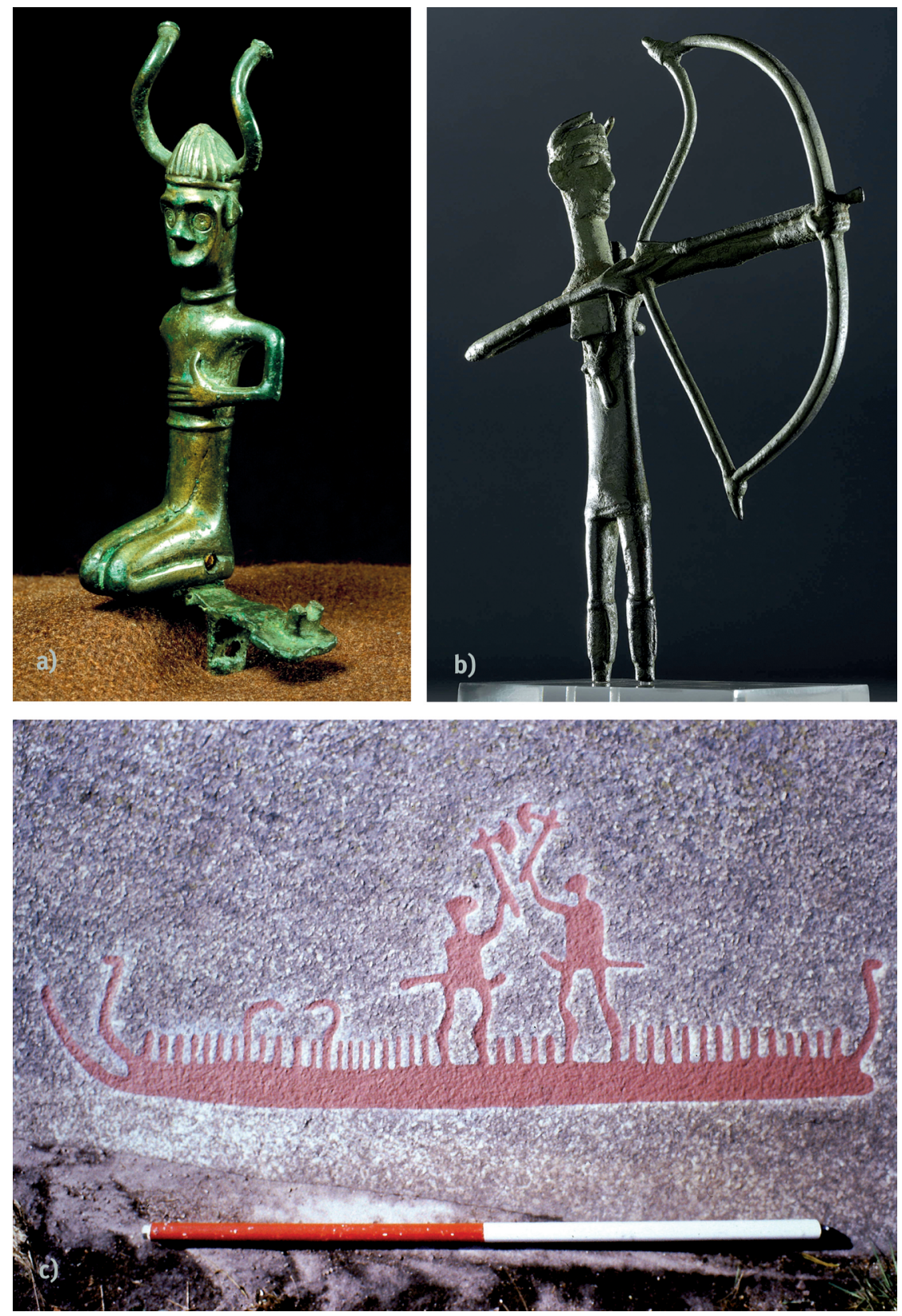

Fig. 2.1: Bronze Age people as shown on bronze figurines and rock art. a) Grævensvænge warrior; photo: Lennart Larsen, Creative Commons licence; b) Sardinian warrior with helmet and bow; photo: British Museum, Creative Commons licence, (c) Trustees of the British Museum; c) warriors on rock art panel from Fossum, Sweden; photo: author. 
Italy (Montecchio). ${ }^{1}$ In 2001, we learned of the Nebra disc (Meller 2010), the meaning of which is still controversial, but for most archaeologists a genuine Bronze Age object and truly extraordinary. A host of less spectacular objects have supplemented these most remarkable pieces, all of which have added to the complexity and diversity of the picture of Bronze Age life. This is to say nothing of the results of systematic or rescue excavation, some of which have also been remarkable. At the risk of offending some archaeologists who believe that their site is supreme in this respect, one may mention particularly those sites with good preservation of organic remains, particular wetland sites such as Must Farm, Cambridgeshire (eastern England) (Knight et al. 2019), or many sites in the sub-Alpine areas of Europe; Nola in Campania, where the remains of Bronze Age houses buried in an eruption of Vesuvius were found (Albore Livadie 2002; Albore Livadie et al. 2018; Laforgia et al. 2009), the stratified settlement of Százhalombatta on the Danube south of Budapest (Poroszlai 2000; Poroszlai \& Vicze 2005); copper mines in the Austrian Alps (Stöllner et al. 2006 (2009)), north Wales (Dutton \& Fasham 1994; Williams 2013; https://www.greatormemines.info/) or southern Ireland (O’Brien 2004); or detailed study of funerary monuments like that relating to barrows on the Utrecht Hill Ridge (Fontijn 2010). At the risk of being accused of promoting my own work, I can also mention the remarkable discoveries connected with salt extraction at various locations in northern Transylvania (Romania), notably the site of Băile Figa near Beclean (Harding \& Kavruk 2013). As well as excavations, survey work in many places has also added enormously to our knowledge of ancient settlement patterns; while the heyday of extensive surface survey work was in the 1980s and 1990s, many areas continue to benefit from this type of approach, for instance the Benta Valley in Hungary or the Thy landscape in Jutland (Earle \& Kristiansen 2010), as well as in many parts of Mediterranean countries.

At the same time, stable isotope studies have added extraordinary detail to what had previously only been inferred from artefact studies about the movement of people, and about diet, while advances in the recovery of DNA from ancient bone has meant that it has been possible to determine crucial aspects of genetic history spanning thousands of years.

It is perhaps ironic that in order to talk about the life of Bronze Age people, one has to rely so often on those same people through their death. It is usually their preserved skeletal remains that are available to us; they can tell us a lot about their life, though it is also how the skeleton was buried, and what with,

1 http://www.archeobologna.beniculturali.it/re_montecchio_emilia/tazza_montecchio.htm, accessed 27 June 2019. 
that gives us most information. Here I shall concentrate on more intangible things, starting with the question: who were the people who occupied Europe during the Bronze Age? What were they genetically? And what, if anything, does this tell us about ethnicity and language?

\section{Who were the people of the Bronze Age?}

In considering the identity - genetic, ethnic, linguistic - of any past people, we enter a whole area of study that has been something of a minefield for reputations, involving as it does debates about, for instance, the area of origin, and the date of the spread, of Indo-European languages. Since we know that the inhabitants of Mycenaean Greece spoke an early version of Greek, it is evident that Indo-European (I-E) language had penetrated at least the south-easternmost part of Europe by the Late Bronze Age at the latest, and probably considerably earlier. It is uncertain how and when I-E arrived in Greece; its nearest geographical neighbour, Hittite, is generally regarded as akin to I-E but distinct from that family in a number of ways. There are no certain survivals of language or even writing in other parts of the prehistoric Balkans prior to the Iron Age, let alone central Europe, which might come to the help of prehistorians. ${ }^{2}$

As we shall see, some scholars have long supposed that I-E moved into Europe during the Copper Age, ${ }^{3}$ and was associated with a particular cultural phenomenon, the Yamnaya Culture in the south Russian and Ukrainian steppe (in German Grubengrabkultur or Ockergrabkultur, formerly called in English the Pit Grave Culture (Russian yama = pit), which is what Marija Gimbutas called it in her publications of the 1960s and 70s; it refers to a specific grave type spread across large parts of the Russian and Ukrainian steppe in the Copper Age. Such graves were placed under barrows, or kurgans; hence Gimbutas' development of the idea of "kurgan people" who she saw as being responsible for both Indo-European language and other crucial elements of European Bronze Age culture. This is a purely archaeological argument, based on shared cultural manifestations (grave practices and artefacts), since there are no actual indications of language. Such arguments are notoriously subjective in character, but as we shall see in this case recent work has come to our aid.

2 I except one-off and controversial finds such as the Tărtăria tablets; most recently Merlini \& Lazarovici 2008.

3 Most notably Marija Gimbutas, in several works, e.g Gimbutas 1965; Gimbutas 1982. 


\section{Archaeogenetics}

The astonishing advances of recent years in the field of archaeogenetics have led to a reappraisal of the genetic origins of Europeans, of all periods. Some of these studies have been on modern populations, relying on the identification of specific genetic markers, or rather the changes in the genome known as SNPs (single nucleotide polymorphisms) that have taken place at various times in the past, thus enabling a genetic history of present-day populations to be built up; others, until recently less common because of contamination problems, have relied on the extraction of genetic material from ancient bones or teeth. The last few years have seen regular reports in the scientific press of how human ancestry - and by that I mean the developmental history of past human populations, not just human origins - has become better known. In particular, a series of articles in the last five years has shed light on the origins of later prehistoric peoples in Europe.

A number of articles have dealt with a somewhat earlier period than the Bronze Age, specifically the genetic origin of Neolithic populations, and the extent to which they show an indigenous hunter-gatherer inheritance, and to what extent an inheritance coming from elsewhere. This work goes back to at least 2010, when Wolfgang Haak and colleagues presented data that showed a Near Eastern ancestry for Neolithic farmers in central Europe (Haak et al. 2010). But things have moved on since then.

An analysis by Gerling and colleagues of eight individuals from an Early Bronze Age burial mound in Hungary showed the existence of non-local individuals among those buried (Gerling et al. 2012). Archaeologically speaking, the kurgan is linked to Northern Pontic Yamnaya groups, because some of the elements in the burial mode were alien to the local area, even suggesting perhaps that the individuals buried in the mound had migrated from the East into the Great Hungarian Plain. Strontium and oxygen isotope analyses reveal an earlier period of "local" burials, spanning the period 3300-2900 BC, followed by later burials that exhibit non-local isotopic signatures. The combination of the isotope values and the grave-goods associated with the non-local burials point to the foothills of the Carpathian Mountains as the nearest location representing a possible childhood origin of this non-local group.

In April 2013 an article in Nature Communications presented the results of a study of mitochondrial DNA in ancient and modern populations, and specifically haplogroup $\mathrm{H}$, which is dominant in modern western European populations (Brotherton et al. 2013). This haplogroup was not common in Early Neolithic farmers in central Europe, and absent in most hunter-gatherer populations, but became commoner during the Middle Neolithic and much commoner by 
the Late Neolithic. Of particular interest for the study of post-Neolithic populations is the finding that there were contributions to the emergence of this concentration in central and western Europe from Beaker individuals, while the following Early Bronze Age individuals studied (Únětice culture) continued the same trend - the genetic distance between Early Neolithic and Early Bronze Age was the greatest, in other words, there was a significant input of genetic material from elsewhere during the Neolithic, which became expressed most notably in late Copper Age and Early Bronze Age populations. Interestingly from an archaeological point of view, mitochondrial genomes from Bell Beaker individuals in central Germany display close genetic affinities to present-day Iberian populations. Corded Ware individuals had two distinct mitochondrial genomes, not found in Bell Beaker individuals from the same area; while Unětice individuals show haplotypes linked genetically to modern populations both east and west of central Europe, in other words a mixed genetic heritage. A Sardinian Bronze Age individual had a previously unknown haplogroup subtype. The authors of the paper stress the link between a gene flow (and thus a movement of people) from west to east in the Corded Ware and Beaker periods, and the long-debated question of the nature of the Beaker phenomenon, for which an Iberian origin is now virtually certain, at least for the so-called Maritime element of the assemblage. This may have implications for language as well, as I shall discuss shortly.

An article in 2014 by a different group considered "genome flux and stasis" across the Neolithic, Bronze and Iron Ages in Hungary (Gamba et al. 2014). The Neolithic results start with a close correspondence with hunter-gatherer genomes and stayed relatively unchanged for 2.5 millennia; the big change came after that, and for the Bronze Age the two samples lie squarely in the modern Central European genome. The Iron Age saw changes again, with a shift towards East European genomes, suggesting influence from the steppe zone.

Two studies from 2015 looked at the ancestry of later prehistoric populations. One, by a group led by Wolfgang Haak and Iosif Lazaridis, analysed 69 ancient individuals across Eurasia, from the Neolithic to the Iron Age (Haak et al. 2015). They looked at the genetic ancestry of populations in western and eastern Europe, identifying separate western and eastern hunter-gatherer ancestral types. But the easterners were very different, in that they had a second genetic aspect, deriving from the Yamnaya. More important still, Late Neolithic groups, notably those who made the pottery known as Corded Ware and spread over much of central and northern Europe, traced a large part of their genetic ancestry to a Yamnaya steppe background. To quote the authors of this paper:

"Western and Eastern Europe came into contact 4,500 years ago, as the Late Neolithic Corded Ware people from Germany traced $75 \%$ of their ancestry to the Yamnaya, documenting a 
massive migration into the heartland of Europe from its eastern periphery. This steppe ancestry persisted in all sampled central Europeans until at least 3,000 years ago, and is ubiquitous in present-day Europeans. These results provide support for a steppe origin of at least some of the Indo-European languages of Europe...

Our results support a view of European prehistory punctuated by two major migrations: first, the arrival of the first farmers during the Early Neolithic from the Near East, and second, the arrival of Yamnaya pastoralists during the Late Neolithic from the steppe. Our data further show that both migrations were followed by resurgences of the previous inhabitants: first, during the Middle Neolithic, when hunter-gatherer ancestry rose again after its Early Neolithic decline, and then between the Late Neolithic and the present, when farmer and hunter-gatherer ancestry rose after its Late Neolithic decline. This second resurgence must have started during the Late Neolithic/Bronze Age period itself, as the Bell Beaker and Unětice groups had reduced Yamnaya ancestry compared to the earlier Corded Ware, and comparable levels to that in some present-day Europeans".

Another study, led by Morten Allentoft and Martin Sikora from Copenhagen, was also published in Nature in 2015, and studied the genomes of 101 ancient individuals of Bronze Age date from various parts of Eurasia, from northern Italy and Germany right across to Siberia (Allentoft et al. 2015). To quote the authors:

"By analysing our genomic data in relation to previously published ancient and modern data, we find evidence for a genetically structured Europe during the Bronze Age. Populations in northern and central Europe were composed of a mixture of the earlier hunter-gatherer and Neolithic farmer groups, but received 'Caucasian' genetic input at the onset of the Bronze Age. This coincides with the archaeologically well-defined expansion of the Yamnaya culture from the Pontic-Caspian steppe into Europe. This admixture event resulted in the formation of peoples of the Corded Ware and related cultures.... Although European Late Neolithic and Bronze Age cultures such as Corded Ware, Bell Beakers, Unětice, and the Scandinavian cultures are genetically very similar to each other, they still display a cline of genetic affinity with Yamnaya, with highest levels in Corded Ware, lowest in Hungary, and central European Bell Beakers being Intermediate” (Allentoft et al. 2015, 168).

Close genetic similarity was noted between Corded Ware individuals and those from Sintashta in western Siberia, which "suggests similar genetic sources of the two"; and Sintashta would not then derive from Asia or the Middle East, but rather from a western source.

The authors go further than this: they move on to consider the question of Indo-European language, and come down firmly on a correlation between the indicated influence of steppe cultures on Bronze Age Europe (via the Yamnaya) and the supposed movement of Indo-European speakers from the steppe at some stage during the third millennium BC. "Our analyses support that migrations during the Early Bronze Age is a probable scenario for the spread of Indo-European languages", they boldly state (Allentoft et al. 2015, 171). 
What is more, the Bronze Age populations of most of continental Europe show close genetic similarity to modern day populations of the same area, indicating that in spite of the many migrations and movements that have occurred in historic times, today's Europeans were largely similar in genetic terms to those of the Bronze Age. This is not true of certain southern European groups, notably in Sicily and Sardinia, where the genetic inheritance is much more similar to Neolithic types.

Lazaridis and colleagues examined the genetic origins of the Bronze Age populations of Greece, admittedly in a small sample (Lazaridis et al. 2017). They found that Minoans and Mycenaeans were genetically similar, having at least three-quarters of their ancestry from the first Neolithic farmers of western Anatolia and the Aegean, and most of the remainder from ancient populations related to those of the Caucasus and Iran. The Mycenaeans differed from Minoans in deriving additional ancestry from a source ultimately related to the hunter-gatherers of eastern Europe and Siberia, introduced via a source nearer at hand and related to the inhabitants of either the Eurasian steppe or Armenia. These conclusions are remarkable when considered in the context of early Mycenaean material culture, as represented above all in the Shaft Graves of Mycenae, where an extraordinary variety of objects includes pieces that seem to show an ancestry or origin in the steppe zone far to the east, as well as Crete, Anatolia and Egypt.

More recently, a ground-breaking article by Olalde and colleagues (Olalde et al. 2018) examined the DNA of 400 individuals from various parts of Europe dating from the Neolithic to the Bronze Age, 226 of them associated with Beaker material. While there was limited genetic affinity between Beaker-associated individuals from Iberia and central Europe, thus excluding migration as an important mechanism of spread between these two regions, there was strong evidence for migration elsewhere, particularly Britain. There the spread of the Beaker complex introduced high levels of steppe-related ancestry and was associated with the replacement of approximately $90 \%$ of Britain's gene pool within a few hundred years, continuing the east-to-west expansion that had brought stepperelated ancestry into central and northern Europe over the previous centuries. The analysis also included a smaller number of Bronze Age individuals, who fitted the same pattern, as had previously been established in an analysis of Irish Bronze Age burials (Cassidy et al. 2016).

Mathieson and colleagues, as part of a study of the ancestry of Old World Neolithic populations, analysed the DNA of a small number of Balkan Bronze Age individuals, showing that their genetic make-up was mixed, with both Anatolian Neolithic, Neolithic, Yamnaya and hunter-gatherer ancestry evident (Mathieson et al. 2018). 
This work continues; papers presented at the conference Genes, Isotopes and Artefacts in December 2018 in Vienna included several papers which built on this foundation. Thus Pinhasi, Fernandes and Reich showed very mixed outcomes for the western Mediterranean islands: Sardinian individuals showed no steppe ancestry (perhaps underlining the rather isolated position of the island throughout ancient times), though there was evidence of Iran-related ancestry coming via the Aegean. Sicily, on the other hand, had evidence of both these ancestries, and the Balearics had substantial steppe-related ancestry, though with an increase in Anatolian farmer ancestry over the course of the Bronze Age (Fernandes et al. 2019).

Iosif Lazaridis (2018) recently summed up the genetic evidence as follows:

\begin{abstract}
"Our understanding of the spread of steppe ancestry into mainland Europe is becoming increasingly crisp. Samples from the Bell Beaker complex are heterogeneous, with those from Iberia lacking steppe ancestry that was omnipresent in those from Central Europe, casting new light on the 'pots vs. people' debate in archaeology, which argues that it is dangerous to propose a tight link between material culture and genetic origins. Nonetheless, it is also dangerous to dismiss it completely. Recent studies have shown that people associated with the Corded Ware culture in the Baltics were genetically similar to those from Central Europe and to steppe pastoralists, and the people associated with the Bell Beaker culture in Britain traced $\sim 90 \%$ of their ancestry to the continent, being highly similar to Bell Beaker populations there. Bell Beaker-associated individuals were bearers of steppe ancestry into the British Isles that was also present in Bronze Age Ireland, and Iron Age and Anglo-Saxon England....

Steppe ancestry did arrive into Iberia during the Bronze Age, but to a much lesser degree.... This ancestry was also present in the Aegean during the Mycenaean period $~ 3.5$ kya at $\sim 15 \%$, but was absent from the otherwise genetically similar Minoan culture of Crete who represents the most recent sampled European population without any such ancestry. Both Minoans and Mycenaeans and to a much lesser extent Neolithic samples from the Peloponnese and Bulgaria also had ancestry related to Caucasus hunter-gatherers, suggesting that this ancestry did not come to Europe only via migrations from the steppe, but also independently, perhaps reflecting ancestry from different Anatolian source populations" (Lazaridis 2018, 24).
\end{abstract}

Finally (at the time of writing) another article by Olalde and colleagues has considered the situation in Iberia (Olalde et al. 2019). On the basis of 60 individuals analysed, it was shown that steppe influence increased markedly throughout Iberia during the Bronze Age. The earliest ones (2500-2000 cal BC) coexisted with locals who had no steppe ancestry, but after 2000 some $40 \%$ of the genetic inheritance was of steppe origin, in other words newly arrived people; the $\mathrm{Y}$ chromosome evidence was even more emphatic in this regard, with one dominant lineage replacing that found during the Copper Age. What is more, the evidence shows that more males than females entered the peninsula. 
These recent analyses seem to show incontrovertible evidence for a range of population movements during the fourth and more particularly the third millennium BC; after that, Bronze Age populations in the second millennium built on that Copper Age background. Who, then, were Bronze Age people genetically? Like most of us today (and coming from Britain, scene of multiple incursions and migrations in historic times, I would be the last person to assert ethnic purity), they were a mixture; there was an eastern component, and there was a western component. Genetically, however, most Europeans had moved on from the "pure" early farmer genome that characterises so much of continental Europe in the early Neolithic. It is clear that a very large element in their genomic make-up came from the east, and specifically from the steppe zone of south Russia and Ukraine.

Recent journalistic accounts of this process, derived from these recent articles, have suggested that the latter centuries of the third millennium $\mathrm{BC}$ were dominated by "murderous invaders", "axe-wielding warriors”, "almost unimaginably violent people" (Barras 2019). I will return to the question of violence and warfare in a later chapter; for the present, it seems hard to escape the conclusion that there was a major migration at the time of the late Copper Age, as represented by the Corded Ware and Bell Beaker assemblages. The extent to which this picture is correct is uncertain; if it were the case, one might expect more evidence of trauma on the skeletons of the people who were "replaced". Kristian Kristiansen has espoused a variant of this in suggesting that the Late Neolithic populations of Europe were fatally weakened by an outbreak of plague (Rascovan et al. 2019; also quoted in Barras 2019), which would have made them easy prey for invaders. In this view, the arrival of the Bronze Age was a violent affair, as Neolithic populations were brutally put down by the invaders. Time will tell if this picture is correct.

The "kurgan hypothesis" of Marija Gimbutas, developed in the 1950s and 1960s (Gimbutas 1956; 1965; 1970) and elaborated by her further in later articles, has always split the archaeological community. For those who saw cultural developments as a clear reflection of migrations, it was the obvious catalyst for the developments of the Copper and Bronze Ages that were so evident in the burial monuments across the continent of Europe. John Chapman has suggested that Gimbutas' concern - even obsession - with migration and invasion stemmed from her personal history as a Lithuanian displaced by Russian and German invasion during her lifetime (Chapman 1998). I myself was sceptical about the kurgan hypothesis, as it seemed to raise more questions than it answered, and did not seem to have any obvious connection with the mound-building cultures of the west and north of Europe (Coles \& Harding 1979, 6-7); at the time, explanations based on migrations were becoming unfashionable, development based on 
local situations being favoured in some influential quarters (notably Renfrew 1972). Andrew Sherratt was one of those who always favoured migration as the major factor in the spread of barrow burial in Copper Age Europe, a standpoint which probably bore on his espousal of a version of World Systems Theory as applied to the Bronze Age (below, pp. 119-20); our discussions on the matter did not lead to any mutually satisfying conclusion. ${ }^{4}$ More recently David Anthony has espoused the kurgan hypothesis with compelling arguments (Anthony 2007). In the light of the genetic evidence, it seems clear that I was wrong and Gimbutas and Sherratt (for the most part) right; a striking confirmation of the power of purely archaeological argument. The same can be said for the longheld view by some scholars that the Beaker phenomenon represents a movement of people into lands in which they were not indigenous, a much-debated topic across the twentieth century. Talk of cultural packages, the power of fashion, and the like, while not untrue, seem at last to have given way before the power of DNA analyses.

\section{Language}

If the genetic make-up of Bronze Age populations has now largely been established, is it possible to go further and say what language or languages were spoken? I have alluded above to the assertion by at least one of the teams that genomic input from the Yamnaya on the steppe was very likely concomitant with the spread of Indo-European language. This is of course another long-running debate. Many authorities have tried to pin down the date at which I-E language arrived in Europe, as well as a subset of the debate, the formation of Celtic languages and thus Celtic identity (summary in Chang et al. 2015). In terms of correlating language with people, the scholarly landscape has not changed greatly over recent decades. The movements suggested as indicating a spread of IndoEuropean have ranged from the supposed emergence of "Celtic" peoples in the first millennium $\mathrm{BC}$, through the emergence of Greek speakers around 2000 BC, the spread of Beaker cultures a little earlier, or - to prehistoric archaeologists in many ways the most likely scenario - the spread of farming peoples at the start of the Neolithic, two to three thousand years earlier (Renfrew 1987). The demonstration that Linear B is an early form of Greek, following on from the ear-

4 David Anthony has referred to the disjuncture between the enthusiasm of Eastern European archaeologists for explanations involving migration compared with the reluctance of Western archaeologists for them: Anthony 1997; Anthony 2007, 458. 
lier demonstration that Hittite is also an I-E language, clearly indicated that I-E speakers were present in the second millennium BC, and thus probably considerably before that. If there was a "Proto-Indo-European" language, from which the developed form emerged as many scholars believe, then we could be talking about an emergence, or arrival, hundreds or thousands of years earlier.

In this context, the conclusion by Chang et alii (2015) that statistical phylogenetic analysis strongly supports the idea that I-E came from the steppe zone, at a time period 6500 to 5500 BP (the late Neolithic and Copper Age) seems to add strong weight to this hypothesis. A strong supporter of the "steppe hypothesis" is David Anthony (2007), who has argued forcefully for the notion that the Yamnaya migration to the west brought I-E language with it. This work, argued prior to the advent of the results of genetic analysis, fits well with these latest discoveries, even if one need not agree with every aspect (for instance that there was a Usatovo "dialect" of I-E which spread north and west up the Dniester valley into the TRB area of Poland: Anthony 2007, 359-360).

If the recent genetic work is correctly interpreted - and at least for the time being we need to accept the interpretations advanced - we are indeed faced with a movement or movements of people in the Late Neolithic and Copper Age from the Eurasian steppe into central Europe, and from Iberia into western Europe. Since I-E language can be incontrovertibly demonstrated to be in Europe by at least the middle of the second millennium BC, and probably earlier than that, we end up saying that much of the continent of Europe in the Bronze Age was occupied by people ultimately of steppe origin, who were I-E speakers and ancestral in both genetic make-up and in language to the peoples of Classical antiquity, and thus to ourselves. I myself have always been rather reluctant to imagine that all problems of ancestry for European Bronze Age people can be resolved by appealing to the "great unknown" of the Eurasian steppe, but these studies can hardly make one believe anything other than what is suggested. Of course, an eastern origin merely makes one ask the next question, where did these easterners come from (if anywhere), and why did they move westwards? But that is a question to explore in a different context. The steppe of central Asia covers a vast area, home to many rich and remarkable cultures; disentangling how they interacted with or influenced Europe in the Bronze Age is something that will require a lot more genetic evidence.

All this tells us something about the origins of the populations of Bronze Age Europe in genetic terms, and perhaps about the language they spoke, but it hardly brings them to light as individuals. For this we have to turn to other aspects, based on archaeological survival in the ground and the ways of analysing the evidence that is available. 


\section{Health and longevity}

One scarcely need recall that life expectancy in the Bronze Age was, by our standards, extremely low, though not so much lower than that experienced even in Europe in relatively recent times - in poor urban communities in the $19^{\text {th }}$ century, for instance. Perinatal and infant mortality was very high, as was childhood mortality; if you lived to your teenage years you had a decent chance of getting through your twenties or thirties, though after that your chances declined drastically. The number of people who survived beyond 40 was quite small, and beyond 50 very small. Nevertheless, a few people made it into their 60s, at which point they were very likely something of a wonder to those around them, much honoured and celebrated (unlike today - I suppose the modern equivalent is to live to 100).

Most published analyses understandably concern inhumation cemeteries, usually of the Early Bronze Age; relatively few Late Bronze Age cemeteries have come into consideration, for the obvious reason that they cremated their dead, so the survival of bone is much less good and detailed recording of age and sex much harder. Nevertheless, there are some analyses worth mentioning. At Vollmarshausen, Ldkr. Kassel, for instance, age was determinable in 210 cases in the 260 graves (Bergmann 1997). While there were differences between different areas and grave types, the overall picture was one where one quarter of those buried died before the age of six and a further $14 \%$ before the age of 14 . Teenagers accounted for another $13.5 \%$, while the largest component in this instance was represented by adults between the ages of 20 and 40 (38.5\%). Only $9 \%$ lived beyond that age.

At El Argar in south-east Spain, a large sample (563 individuals) was studied (Kunter 1990): life expectancy at birth was 19.9 years, but at age 20 it was still 15.9 years, in other words teenagers had a reasonable chance of making it into their thirties.

At the Austrian site of Franzhausen I, Margit Berner's analysis of an even larger buried population - 658 individuals - showed infant and child mortality at over 30\%, with teenage deaths at less than $10 \%$ (Berner 1997). The largest single age group at death was of people between 20 and 40 (37\%), while 18\% died between 40 and 60, and remarkably, 3.5\% lived beyond 60 - senilis (senile or maybe not ${ }^{5}$ ) in the official terminology.

In spite of the fact that demographers find the figures for childhood mortality too low, the general picture is clear. While perinatal mortality is perhaps un-

5 "Senile" has a pejorative connotation in English as in German. 
derstandable in societies without a modern understanding of the risks and dangers surrounding birth and early childhood, the health issues affecting people who survived childhood are less evident to us - though the absence of antibiotics must count as one of the biggest factors, as in most premodern peoples. Indeed, when one examines health aspects of Bronze Age populations, a series of factors become evident; a range of pathological conditions affected people.

Fourteen of the adults from the Early Bronze Age cemetery at Grossbrembach, Landkr. Sömmerda (Thuringia), had tooth caries, in some cases extensive (Ullrich 1972). On Italian Bronze Age sites, the incidence varied from as little as $3.3 \%$ to as much as $19.7 \%$ of studied populations, and periodontal disease and dental hypoplasia (deficient enamel) were also found (Borgognini et al. 1995). At Unterhautzenthal caries was rare on the individuals studied, but some had lost a lot of teeth, with one woman in late middle age having none at all in her mandible (Rebay-Salisbury et al. 2018, 88). An individual from an Early Bronze Age cist grave at Leven, Fife (east-central Scotland), had evidence of a tooth abscess (Lewis \& Terry 2004, 43), and a woman in her 40s from an Early Bronze Age site near Inverness in north-east Scotland was generally healthy but had several tooth abscesses (compare a middle-aged woman of Beaker date from West Torbeck near Inverness: M. Kilpatrick http://archaeologyreportsonline.com/PDF/ AR08_WestTorbreck.pdf, accessed 27 June 2019), as did the Amesbury Archer (J. McKinley in Fitzpatrick 2011, 25, 81-2 Plate 27). The bad teeth, complete with abscesses, reminds one of the fate of Thomas Buddenbrook in Thomas Mann's Buddenbrooks (1901). Dying from toothache must be very unusual, but one can certainly suffer excruciating pain from it, as he did; an untreated abscess can infect other parts of the body and eventually lead to death, as happened to the fashion designer Hugo Boss.

A large kidney-stone, $35 \mathrm{~mm}$ across and over $22 \mathrm{~g}$ in weight, was found in the pelvic area of a mature male from Csongrád-Felgyő in Hungary (Boross \& Nemeskéri 1963). Examples of pathological features deriving from chronic illness include Spina bifida, arthritis, particularly of the vertebrae; inflammation-like changes in the bones of the hand; and osteomyelitis. An interesting interpretation is that relating to the incidence of Cribra orbitalia (spongy bone above the eye sockets); it was present on all the subadults and two adults studied at Toppo Daguzzo (Basilicata, southern Italy) (Repetto et al. 1988); it was present at Sant'Abbondio, Pompeii (Tafuri et al. 2003) and many other sites, and considered to be a reaction to parasitic infections that derive from animal breeding and in particular the consumption of untreated dairy products and cattle meat (Minozzi et al. 1994). This feature was also present at El Argar (Kunter 1990, 88ff.), where it is taken to be an indicator of blood iron deficiency, perhaps caused by malaria, at Blučina in southern Moravia (Smrčka et al. 1988), and at Franz- 
hausen I, Gemeinlebarn F, Unterhautzenthal and several other sites (TeschlerNicola \& Prossinger 1997; Teschler-Nicola 1994; Rebay-Salisbury et al. 2018).

Parasitic infections are also highly evident at the wetland site of Must Farm, Cambridgeshire. A recent analysis of coprolites recovered from the site show the presence of numerous helminths (worms): eggs of fish tapeworm, Echinostoma worm, giant kidney worm, probable pig whipworm and Capillaria worm (Ledger et al. 2019). It appears that the wetland environment of the settlement contributed to parasite diversity and put the inhabitants at risk of infection by helminth species spread by eating raw fish, frogs or molluscs that flourish in freshwater aquatic environments. These parasites are spread through human waste and suggest a poor level of hygiene on the site, in addition to the ingestion of parasites directly from the aquatic food sources.

At some of these sites bone trauma was evident; I return to this question below when considering inter-group violence - though of course some of the trauma may have resulted from the daily activities of life (though perhaps not depressions in the skull).

The recent demonstration (Rasmussen et al. 2015) that the plague bacterium Yersinia pestis was present in seven out of 101 Bronze and Copper Age samples analysed, across a broad geographical range from Poland in the west to Siberia in the east, sheds extraordinary new light on health - or lack of it - in later prehistory. While this was probably not, according to the authors, bubonic plague, such as was responsible for the Black Death and its later manifestations, and for other outbreaks of plague such as the Justinianic plague in the sixth century AD and the so-called Third Pandemic, originating in China in the $19^{\text {th }}$ century, its manifestation as pneumonic and septicaemic plague must have been quite severe enough to cause major population problems; indeed, the authors suggest that population declines in the late 4th millennium BC and the early 3rd millennium BC may have been caused by such outbreaks. This is speculative, of course; there is no direct evidence for it. But the periods in the ancient past where there are puzzling gaps in human presence may well emanate from health-related problems, rather than the natural disasters that some scholars prefer to promote. This is the explanation offered by another group in 2019 (Rascovan et al. 2019); a different plague lineage was present in various parts of Neolithic Europe, and may have been responsible for the drastic decline of Neolithic populations in some areas in the later part of the Neolithic.

Given the multifold dangers affecting Bronze Age people, one might wonder that they managed to do anything at all in their brief lives, but of course that is wrong: their achievements were remarkable, and there were a lot of them. Reconstructing the size of prehistoric populations is an imprecise art, to say the least, depending as it does on various assumptions about site numbers and size. A re- 
cent publication covers the matter in exhaustive detail (Nikulka 2016). It is worth pointing out, however, that in the Late Bronze Age, and particularly in period V, the buried population of North Germany and Poland runs into several millions. D.-W. Buck calculated estimated densities of up to 8 people per $\mathrm{km}^{2}$ for this period, as compared with a figure of 1 per $\mathrm{km}^{2}$ or less for the Middle Bronze Age (Buck 1997).

\section{Food and diet}

The discovery that the Egtved girl (below) had been eating a diet poor in protein (Frei et al. 2015, Supplementary information 15) raises a range of questions about the food that people were consuming. In general we know very well that European Bronze Agers were exploiting both animal and plant foods; principally the normal range of domesticates in each case. Cattle dominated the animal spectrum in most areas, the only exceptions being in upland areas where there might have been limited pasture for them; and wheat, barley, and, later on, millet dominated the plants, with plentiful additions of legumes (peas, lentils, later beans) and some other species that are not eaten today, like Camelina sativa (false flax, Leindotter). This much is clear and obvious. But stable isotope analysis enables us to distinguish between terrestrial and marine food sources in the diet of individuals, and between $\mathrm{C} 3$ and $\mathrm{C} 4$ plants (the difference relates to the ability of plants to photosynthesise carbon dioxide; most food plants are $\mathrm{C} 3$, the exception being millet). Marine and terrestrial foods are detected through nitrogen and oxygen isotopes, which indicate the "trophic level" of the subject studied (stage in the food chain); nitrogen indicating animal protein (herbivores have lower nitrogen 15 values than omnivores, which in turn are lower than carnivores); carbon isotopes can distinguish between marine and terrestrial foods, and between $\mathrm{C} 3$ and $\mathrm{C} 4$ plants.

It is evident that food sources changed somewhat during the course of the Bronze Age. While staples like wheat, barley, beans and lentils were present throughout, a major development occurred in Europe in the later centuries of the second millennium BC: a range of new crops began to be intensively cultivated, most notably millet (which starts to appear regularly by around $1200 \mathrm{BC}$ ) but also oil plants like Camelina sativa, poppy and flax, and there was also a move towards other grain crops such as spelt and rye. In part this may have been a desire for diversification, so that risks were spread; in part it was probably a matter of intensification, since millet is fast-growing and can flourish on a wide variety of soils and environments. 
A conference held in Rome in 2015 heard a series of papers dealing with the isotopic analysis of human bones from a range of contexts. The results of one, the spread of values from a Copper Age cemetery at Contrada Scintilia, province of Agrigento, Sicily, is interpreted by the authors as indicating a diet based primarily on C3 farm crops, with some admixture of animal protein (Tykot et al. 2015). At the Middle Bronze Age site of Castiglione, the results fall squarely in the area of terrestrial plants, perhaps with some $\mathrm{C} 4$ plant food being consumed, and again with a clear indication that animal protein was being included. Interestingly, at this site it was possible to see differences in nutrition between the sexes. A study of diet at several Bronze Age sites in mainland Italy showed that C3 plants, probably wheat and barley, were supplemented by millet at Olmo di Nogara (Tafuri et al. 2009). Even in Sardinia, surrounded on all sides by the sea, a recent study showed that marine resources played a negligible role in diet (Lai et al. 2013). The same is true for a recent study of Bronze Age individuals buried in the cave of Cova do Santo in the Lugo district of Galicia, north-west Spain (López-Costas et al. 2015), which showed that they consumed solely C3 plants and animal food, with no fish at all - perhaps not so surprising given the nature of the terrain here and the distance of nearly $90 \mathrm{~km}$ to the sea. Acorns were gathered and apparently used in cooking as well as (potentially) other uses at several sites in Bronze Age Apulia (Primavera \& Fiorentino 2013); although Europeans of the present day do not generally eat acorns (apart from creating ersatz coffee!), certainly not raw because of the tannin they contain, there is plenty of ethnographic evidence that shows that historically acorns have been eaten.

Many other studies have shown that in coastal environments the presence of fish is indicated - hardly a surprise. The balance between fish and land foods is probably most important in marginal environments, and for periods when major transitions in lifestyles were taking place, notably at the end of the last glaciation, or the start of the farming way of life.

The study of vessel contents is also an important method for reconstructing diet. A recent study of vessel contents in Neolithic and Subneolithic contexts from sites in Lithuania (3300-2400 cal BC), including Šventoji, showed that the majority of the vessels were used for processing aquatic products (Heron et al. 2015; Robson et al. 2019). At one site the data suggest exploitation of freshwater resources and, in the later stages of occupation, dairying. Other substances identified include pine resin or tar, and beeswax. At Must Farm, Cambridgeshire, eastern England, the extraordinary range of finds includes fish traps and many fish bones, as well as nettle stew identified from pot contents, with a wooden spoon still stuck to the bottom of the pot (http://www.mustfarm.com/post-dig/ 
post-ex-diary-3-some-initial-findings/, accessed 27 June 2019; Knight et al. 2019; the excavation reports are in preparation).

\section{Identities and occupations}

How people regarded themselves, and how others regarded them, in other words their identities, is a complex matter to which I return in another chapter. But a few things may be mentioned right away. First, we can get some idea of what people actually looked like in life, through depictions of them - either in the round, or as two-dimensional images - or through what they wore and how they presented their hair and skin. In this way various images can be presented, about which I will not say much other than that we presume they have some reality in reconstructing Bronze Age appearances. The well-known and well-preserved clothing items from oak coffins in Denmark need not be dwelt on here, other than to say that we do not actually know how typical they were of particular age and gender sets. Hairstyles seem to have differed widely, for both women and men, perhaps marking age or rank distinctions, marriage status, or special occasions (Fig. 2.2).

There is a lot that could be said about how Bronze Age people actually spent their lives, once they had survived childhood. We know from textual sources in the Near East and Greece of a large range of occupations; the Linear B tablets alone tell us of agricultural workers, shepherds, woodsmen, bronzesmiths and goldsmiths, potters, spinners and weavers, flax-workers, grain-processors, bakers, and many more. In the barbarian world, in the absence of written sources we are obviously much less well informed, but we can certainly be sure of the existence of potters (male or female) and bronzesmiths, no doubt carpenters and other specialists in wood-working too. The smith in particular, to judge from ethnographic and historical or semi-historical evidence, must have occupied a very special place in society. This is probably one of the identities which we can reconstruct with some plausibility; a certain number of graves contain smithing equipment such as moulds and hammers, which are interpreted, rightly or wrongly, as indicating the profession of the occupant of the grave (Jockenhövel 1982) (Fig. 2.3). Smithing was apparently not restricted to men: a grave at Geitzendorf, Lower Austria, contained a body identified as female along with a curious collection of artefacts, including four cushion stones, perhaps used for gold working (Lauermann \& Pany-Kucera 2013). The same seems to apply to salt-workers, given the presence of finds of briquetage in certain graves, mainly in northern Germany (Jockenhövel 2012) (Fig. 2.4); and it has also been suggested that women worked in the Hallstatt salt mines as well as men (Pany 

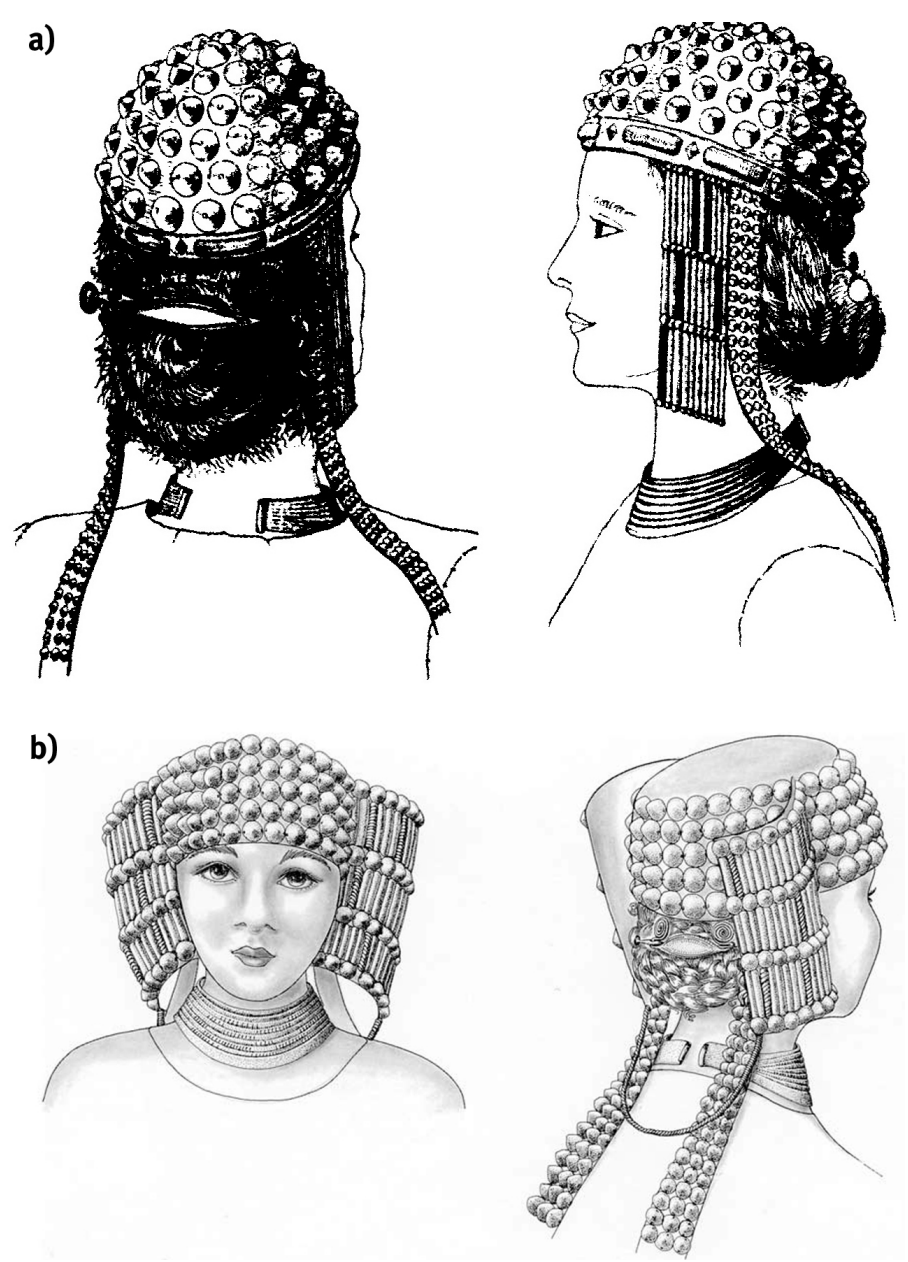

Fig. 2.2: Hairstyles in Bronze Age people. a): Bleckmar; source: Piesker 1958; b): Lüneburg; source: Bergerbrant 2007, after Ulrike Wels-Weyrauch.

\& Teschler-Nicola 2007). Mining, for copper as well as other minerals, may well have been conducted by children as well as adults, to judge from the narrowness of the shafts and adits at both the Mitterberg and the Great Orme in North Wales.

One of the things that we know people did in the Bronze Age was to fight, or at least to cultivate a warrior identity. I discuss societal conflict and the role of war in another chapter; the evidence for conflict is extensive and in this, the rise of the warrior is a crucial part of Bronze Age life. The date at which the first indications of the warrior identity appear is disputed; the first weapons bur- 

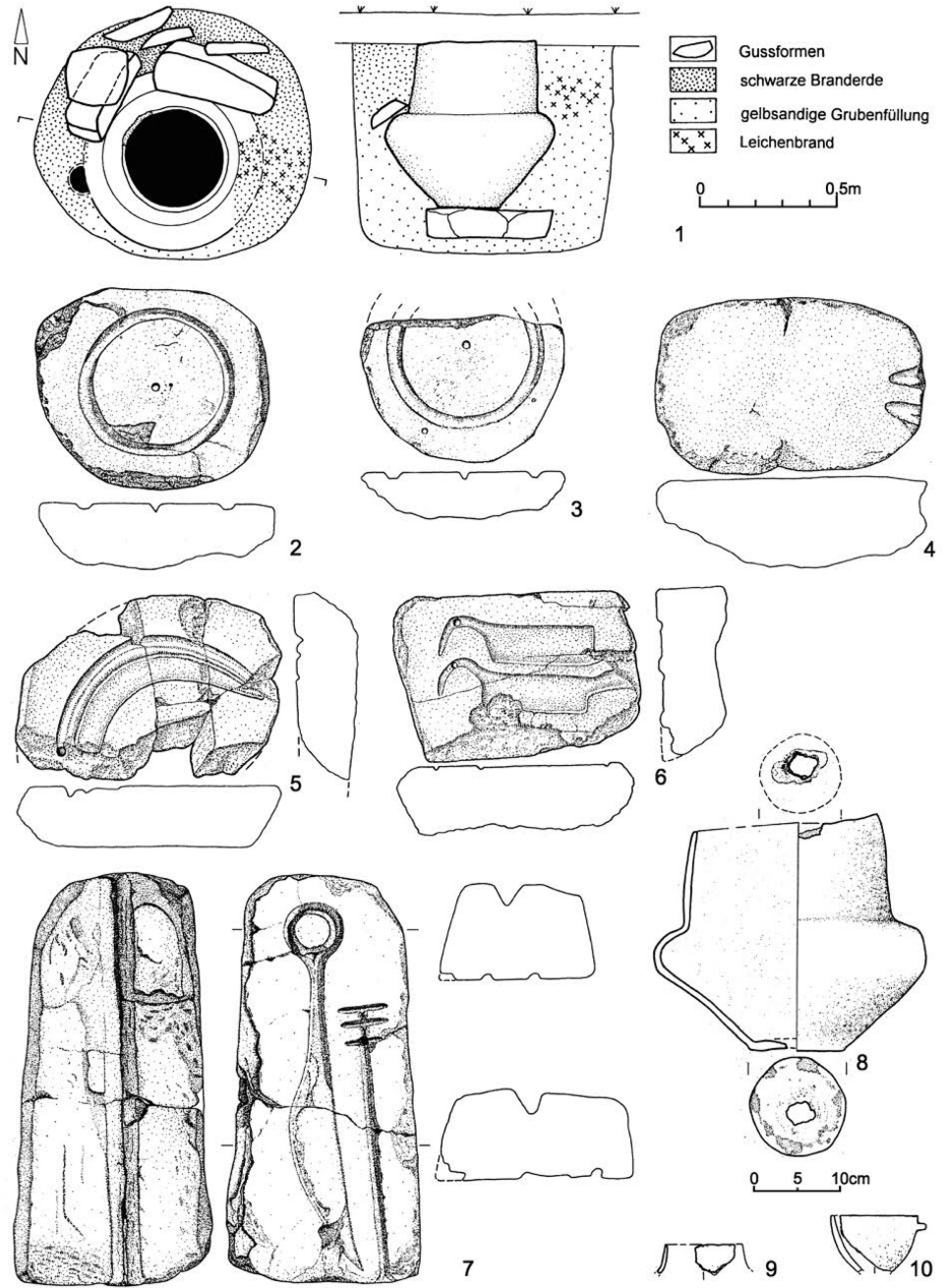

Fig. 2.3: Late Bronze Age graves from Germany containing metalworking equipment. Source: Jockenhövel 2012.

ied with people occur during the earlier part of the third millennium, and Italian archaeologists are adamant that burials of the Remedello culture show incipient warrior status. Further north, Beaker burials often include daggers, and depictions on statue-stelae clearly show us special people bearing weapons (Ambrosi 1988; De Saulieu 2004; Gallay 1995), while the practice of showing armed men on grave stelae continued much later (Grosjean 1961; Almagro 1966) (Fig. 2.5). In my opinion, however, the crucial step towards a fully-fledged warrior society came 


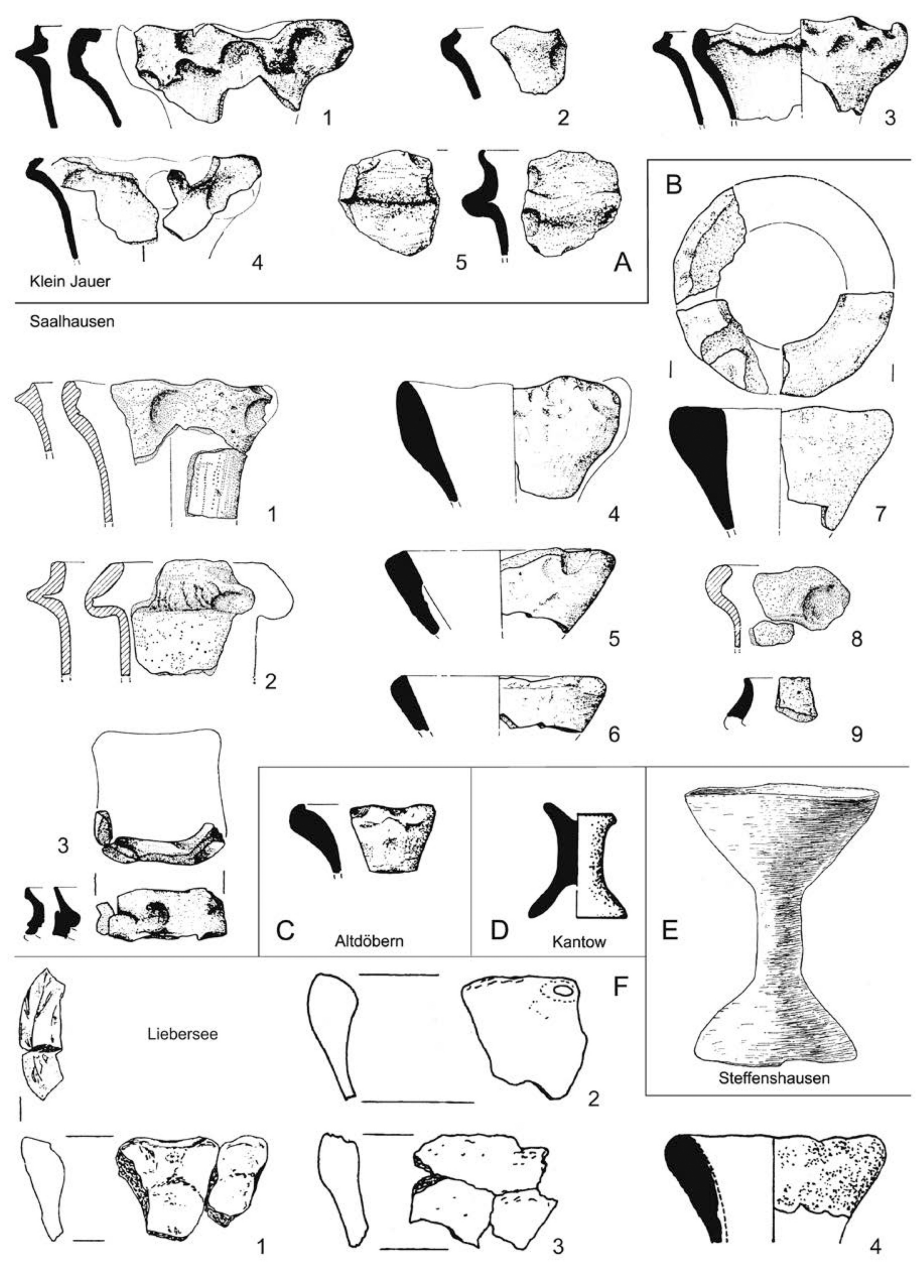

Fig. 2.4: Late Bronze Age graves from Germany containing briquetage. Source: Jockenhövel 2012.

with the invention of an item specifically designed to cause damage to other humans: the sword (Fig. 2.6). You can use daggers and spears in hunting, but you only use a sword against people. From the middle of the second millennium BC graves, usually male, increasingly contain both swords and other war-related equipment like spears, and sheet bronze armour was developed. I have argued in the past that by later stages of the Bronze Age it is likely we are seeing the existence of warrior bands comparable to the comitatus of Tacitus or the Gefolgschaft of the early medieval period (Harding 2007, 162ff.). Group warfare re- 
placed the small-scale conflict that had been the hallmark of earlier periods. I shall return to these matters below (pp. 112-14).

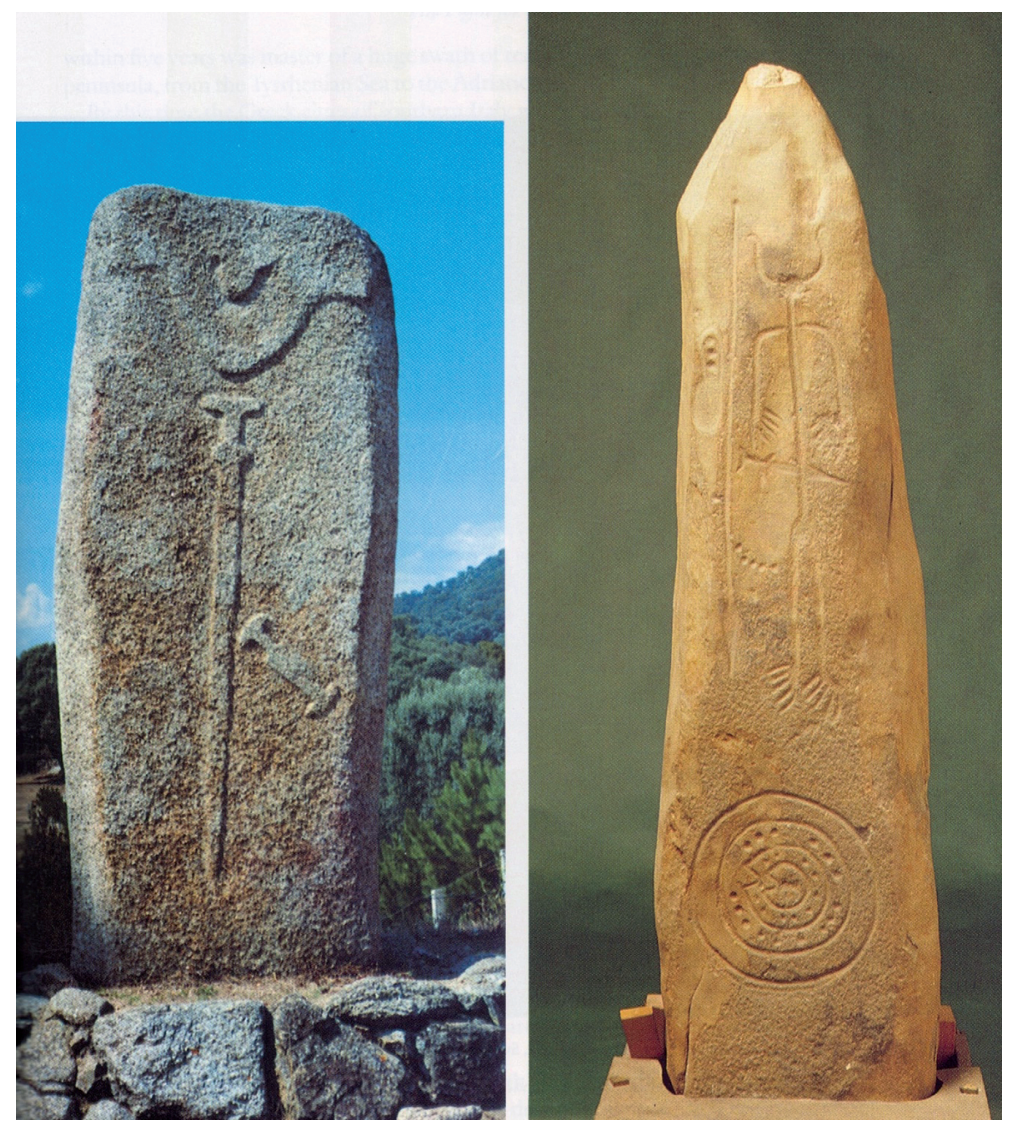

Fig. 2.5: Grave markers ("statue-menhirs") showing men bearing weaponry. Left: Filitosa, Corsica; right: Magacela, Badajoz, Spain. Source: Harding 1994.

There were probably also other special people around. Sabine Gerloff has suggested that the gold cones found in several parts of Europe served as hats for magicians (Gerloff 1995) (Fig. 2.7), while the gold cape from North Wales obviously marked out some other very special person (Powell 1953). The extraordinary range of heavy Irish gold ornaments (most notably the collars with disc terminals) may indicate special people; the "bullae" known from Ireland and Britain may represent other examples (Eogan 1998; Cahill 2018; Hilts 2019) 


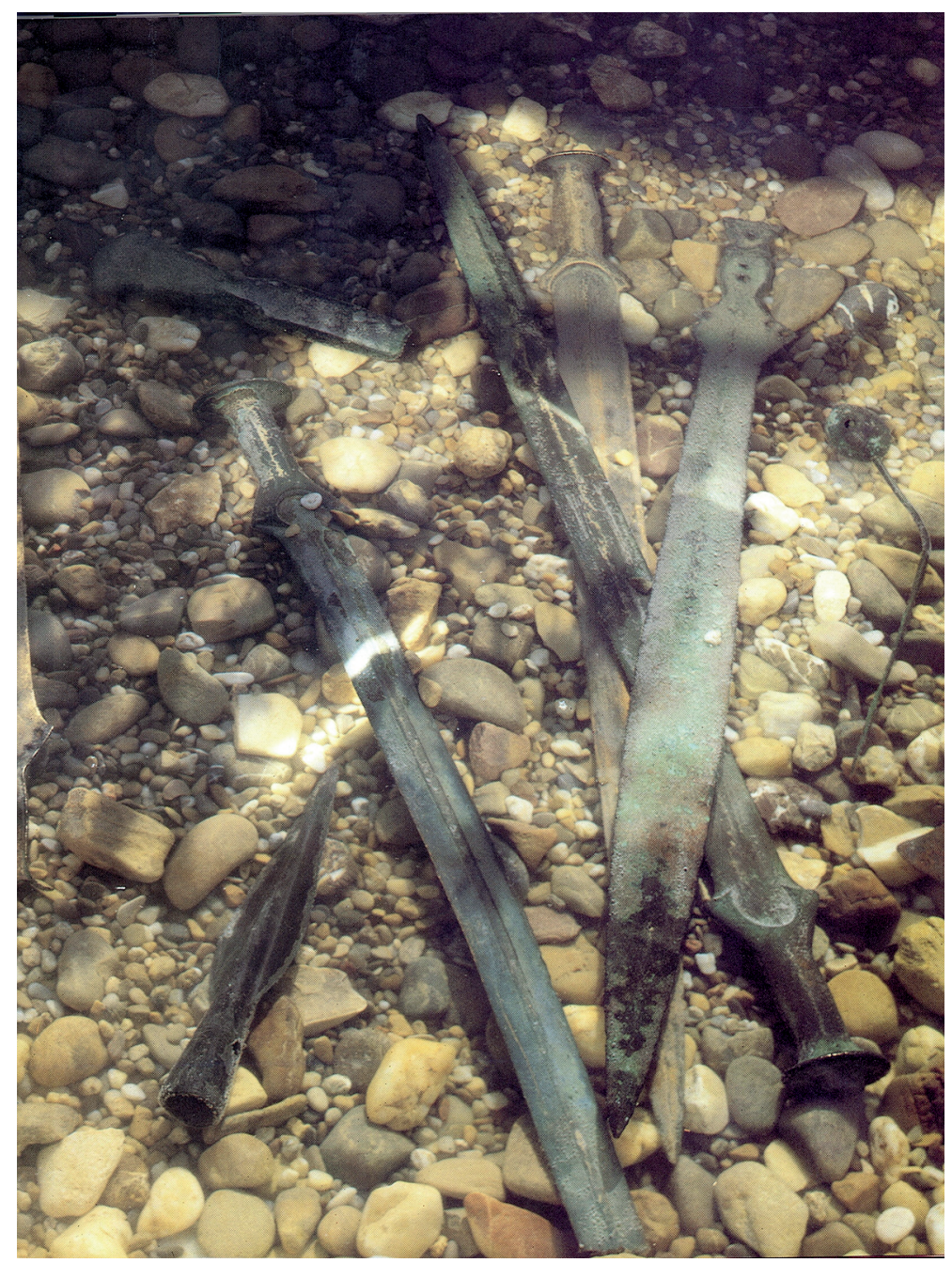

Fig. 2.6: Late Bronze Age swords, as formerly displayed in the Archäologische Staatssammlung, Munich.

And if we interpret the Nebra disc correctly as an astronomical device, there were astronomers as well, people with a range of very special knowledge. 


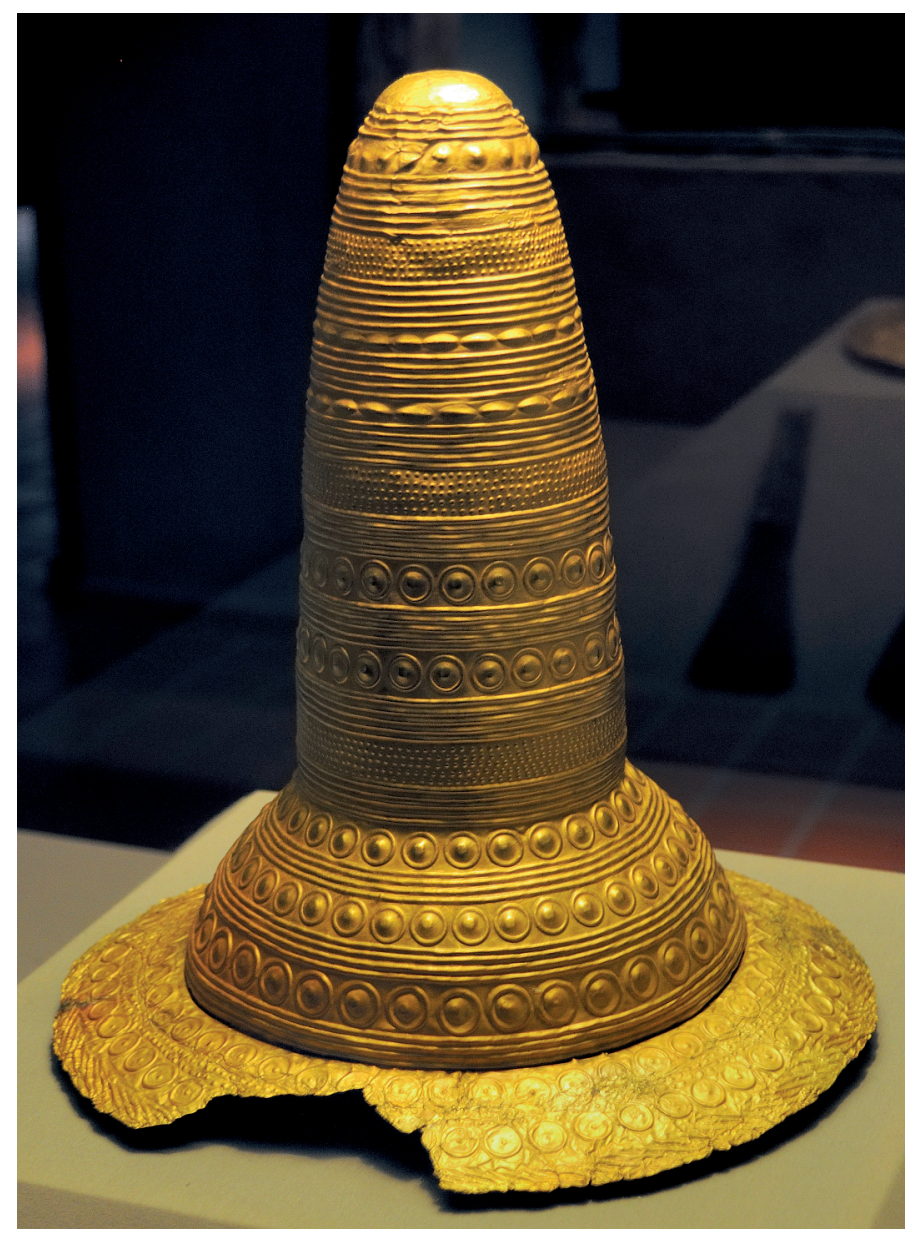

Fig. 2.7: The gold cone from Schifferstadt, Rhein-Pfalz-Kreis. Photo: DerHexer, Creative Commons licence.

\section{Traders and travellers}

The other identity we can reconstruct through proxy evidence is that of the traveller. We have long believed that people moved around in the Bronze Age; artefact distributions provide strong evidence for it, and the demonstration by Albrecht Jockenhövel (1991) that ornaments in Middle Bronze Age women's graves in parts of central and western Germany very likely indicated movement in marriage was a sophisticated use of artefacts to provide archaeological evi- 
dence for such movement. But since then we have the results of stable isotope analysis to bring into play. I need hardly mention the well-known Amesbury Archer (Fitzpatrick 2011), a mature Bell Beaker period man found a few kilometres from Stonehenge, whose birthplace was not in Wessex, or even in southern England, but somewhere in continental Europe, perhaps Germany; or the nearby Boscombe Bowmen, who had moved twice during their lifetimes, being born somewhere with a quite different radiogenic signature, moving somewhere else around the age of 9, and ending up on the chalklands of Wessex. Of the young men from Neckarsulm, Kr. Heilbronn, around one third of the 37 individuals analysed were not indigenous to the area but came probably from some other part of south-west Germany (Wahl \& Price 2013); Pokutta (2013, 181ff.) found extensive evidence for the movement of individuals across the territory of Lower Silesia in the Early Bronze Age, including children. One must note, however, the individuals from Singen, Kr. Konstanz, where no evidence for mobility was found (Oelze et al. 2012); similar conclusions were reached for Early Bronze Age individuals in cemeteries in central Germany (Knipper et al. 2016); there was some evidence from the isotopic data for non-local individuals, but the burial rite alone could not distinguish them. A study of twelve individuals from a collective burial under a Mycenaean building at Thebes, central Greece, found that one person had spent her latter years or months in a different environment from the one where she was buried (Vika 2009).

These important results are now joined by an even more spectacular one, the burial of a young woman at Egtved in Jutland, the original find being made in 1921 (Thomsen 1929). The grave is remarkable for the clothing found with it (Broholm \& Hald 1940); it dates to Period II of the Nordic Bronze Age, the last treering preserved being 1370 BC (Randsborg \& Christensen 2006, 221). It has now been the subject of a range of biomolecular and biochemical analyses (Frei et al. 2015) which have shown that far from being a stay-at-home Danish girl, she was in fact much-travelled and probably from somewhere quite different in continental Europe: the authors suggest the Black Forest as her place of origin (though other areas are also possible). Additionally, the wool used in her clothing mostly came from sheep which were not local to the area. In her last two years of life, and especially in the final months, she had travelled a lot, as analysis of her hair showed. What is more, while she was eating a terrestrial (landbased) diet, she was lacking in protein, in other words she was not the healthy young blonde often depicted, but perhaps something rather less alluring, at least to our modern eyes.

This startling information has been supplemented by the study of another Danish Bronze Age female, the young woman from Skrydstrup (Frei et al. 2017), dating to Period III of the Nordic Bronze Age; the recent radiocarbon 
date puts it at $1306-1188 \mathrm{BC}$ at $78 \%$ probability, i.e. most likely the $12^{\text {th }}$ century $\mathrm{BC}$, with a small probability it lies in the $11^{\text {th }}$ or $13^{\text {th }} ;$ dendro dating on the preserved wood was unsuccessful (Randsborg \& Christensen 2006, 233). This woman lay on an ox hide in an oak coffin under a large turf mound, and was accompanied by a horn comb and a set of gold spiral rings; her clothing and wool cap survived, along with a belt around her body (Broholm \& Hald 1939; 1940) (Fig. 2.8). She was around 17-18 years old when she died, and she moved from her place of origin - outside present day Denmark - to the Skrydstrup area 47 to 42 months before she died. She was thus around 13 to 14 years old when she migrated to that area, where she lived for the rest of her life. This raises interesting questions about the movement of girls and young women, perhaps in marriage - as Albrecht Jockenhövel suggested in 1991.

It is necessary to mention, however, that recent work has raised questions about the use of strontium isotopes for provenance testing, given that lime spread on fields in agricultural activity can cause $\mathrm{Sr}$ isotope ratios to change (Thomsen \& Andreasen 2019); in this study, the natural variation in Sr isotope ratios in the areas around the Egtved and Skrydstrup burials is said to fall in the range obtained on the burial material. These problems are being addressed by the team that presented the original studies (Hoogewerff et al. 2019), and may not invalidate their conclusions. ${ }^{7}$

All these indications tell us something very important. People moved about during the Bronze Age. I have to modify my own published statements in the light of these findings. I have always believed, and stated in print, that most people in later prehistory, including the Bronze Age, were basically tied to the land; they were peasant farmers, who were concerned above all to gain what they needed from the land in order to survive, and of course to take part in the major episodes of monument building that we can discern archaeologically. Now of course we do not know how many people spent their lives travelling like the Egtved girl, or indeed moving just once during their lifetimes, as perhaps the Amesbury Archer did; nor can we be sure that people buried in oak coffins in large tumuli were not very special people, who had done things that most people didn't. I would still imagine that most people did not travel far, or much beyond their immediate confines, for the local exchange of foodstuffs and locally produced commodities like skins, wool, stonework, metal tools and the like. But clearly we have to recognise that some people did travel, and they travelled fre-

6 A date obtained in the 1980s put it rather later.

7 I thank Professor Karin Frei for her thoughts on this matter. 


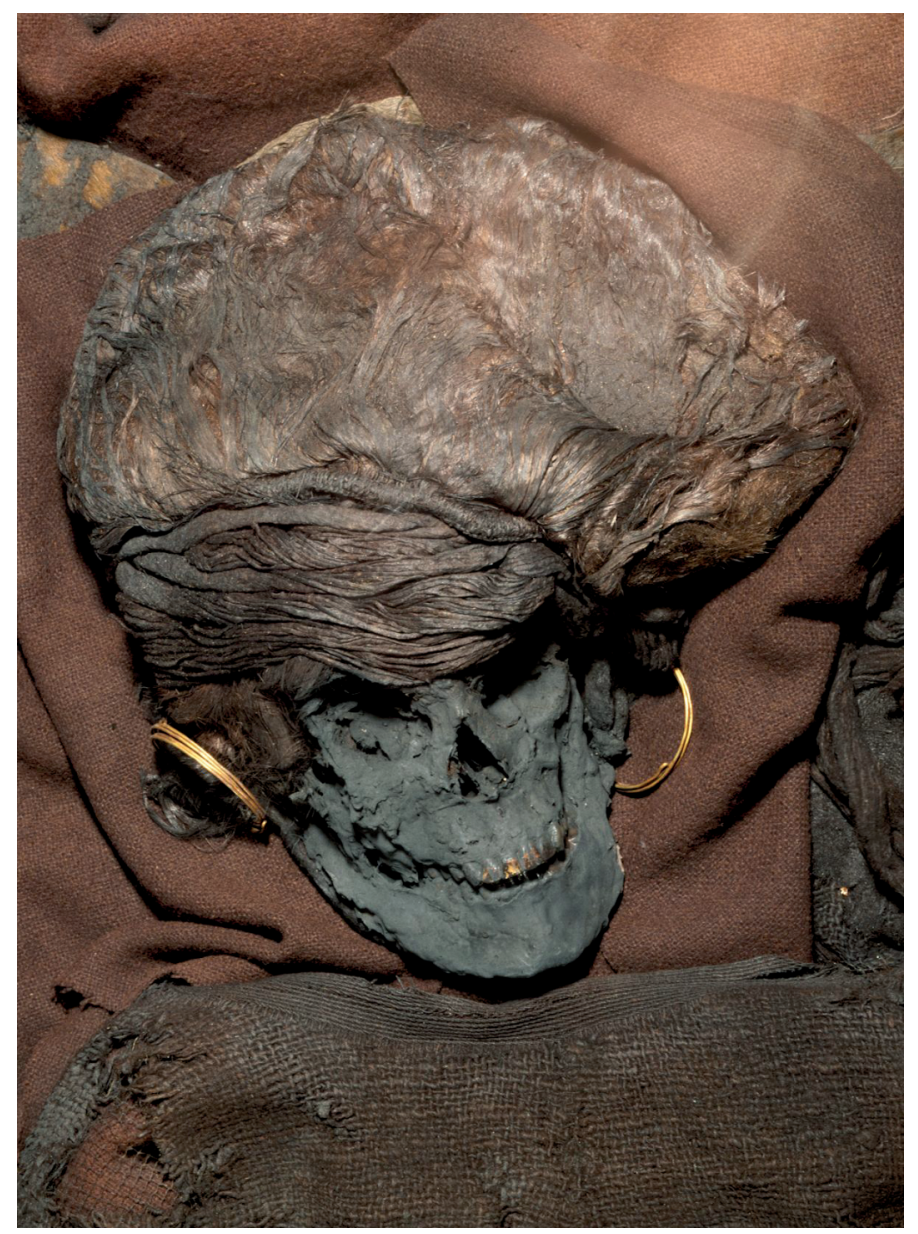

Fig. 2.8: The head of the woman from the Skrydstrup barrow, as found. Photo: Danish National Museum.

quently, and over long distances. I shall return to these topics later, when I consider the nature of the "Bronze Age world" (below, p. 115).

Work currently under way is investigating the movement of people on a very local scale: a study of burials from the Lech valley near Augsburg in Bavaria is showing remarkable evidence for the presence of non-local females, with patrilocality being the dominant residential system; the discussion has also been able to associate sex and kinship aspects with those relating to inequality (differential 
access to material goods). ${ }^{8}$ Some aspects of this ground-breaking project were published earlier (Knipper et al. 2017).

How does this compare with artefactual evidence? It is hardly news that many objects were moved both short and long distances across the continent in the Bronze Age. I shall discuss some of these objects in a later chapter (for instance the extraordinary bronze “drum” from Balkåkra in southern Sweden); objects such as the Cypriote spearheads, found in various places in central and western Europe, are equally striking (Gerloff 1975). Their stories are best told, however, when we come to consider object biographies.

All this would suggest that we can confirm the picture of long-distance trade which I and others have been suggesting for many years. I have always believed that materials like amber were surely transported around the Bronze Age world, so someone must have taken them - in this case from the major sources on or near the Baltic to central Europe and indeed across the Alps to Italy and Greece. Some scholars, Kristian Kristiansen notable amongst them, would go much further and imagine that Europe in the Bronze Age was a constant scene of travel and trade. These latest findings clearly suggest that his maximalist position is becoming more likely. Bronze Age Europe was a place where movement was the norm, not the exception.

\section{Status and role}

Identifying what people did is one thing; saying what their role in society might have been is quite another. How did people relate to each other, and how to society as a whole? Inevitably we are here considering the evidence provided by personal possessions as represented by grave-goods. And that evidence very often indicates that grave-goods, and perhaps therefore possessions, are unequally distributed through society: some people are buried with many more objects than others. (For present purposes I ignore the possibility that grave-goods are not personal possessions; even if they are not, an abundance of goods suggests that numerous gifts were offered at the time of the funeral, which in itself suggests an enhanced importance of the individual being buried.) Differential provision of goods may thus be taken to indicate inequality in death; and, one presumes, inequality in life.

8 Paper presented at the Vienna conference “Genes, Isotopes and Artefacts”, December 2018, by Corina Knipper and others. Now (September 2019) in press: Mittnik et al. 2019. 
Here we enter a quite separate discussion, about inequality, which I have discussed in previous accounts (Harding 2015). The way in which inequality is assessed in modern sociology is through the use of the Lorenz curve and the Gini coefficient; a number of authors have applied these methods in archaeology (e.g. Windler et al. 2013) though it is arguable whether the results tell us much more than was already apparent from the archaeological finds. ${ }^{9}$

The study of inequality in prehistoric archaeology is by the very nature of the evidence difficult; many prehistorians are reluctant to go beyond the most elementary conclusions derived from grave wealth or house size. Sociologists and anthropologists are less afraid of manipulating what they see as data, however, as recent studies have shown: studies by Turchin, Whitehouse and others study social complexity through the analysis of material assembled in the databank "Seshat" (Turchin et al. 2017; Whitehouse et al. 2019). These procedures may be valid in the case of literate societies where there is written confirmation of institutions, religious and administrative; but as an examination of Seshat shows, for prehistoric cultures most of the relevant data are missing. Such problems are bound to beset such formulations as "the Axial Age", originally identified by the philosopher Karl Jaspers in a book of 1949 (Jaspers 1953) ${ }^{10}$ and the works of those who have subsequently attempted to formalise the concept, and said to fall in the period roughly $800-300 \mathrm{BC}$. In the world of prehistoric Europe, the first millennium BC clearly saw major developments in society and technology, but only with literacy is it possible to identify securely the "moralizing gods" who some have claimed to be responsible for the rise of complex societies in that period.

\section{The end of life}

I have talked about various aspects of people in the Bronze Age, who they were and how they lived. As I said at the start, we know most about people from what happened to them when their lives ended - which of course they all did. I shall not discuss here graves or cemeteries; that would turn into a catalogue of different forms, body positions, and so on. But since death is a universal aspect of life,

\footnotetext{
9 The problem with using this approach is that it depends on income rather than wealth. While there might be a connection between the two in ancient societies, the concept of "income" in the Bronze Age is clearly problematic.

10 Achsenzeit, perhaps better translated as "Axis time" or "Revolution time", indicating the notion that the period in question (mid first millennium BC) was a time around which civilisations "revolved".
} 
it is worth looking briefly at what we can say about people's attitudes to death and the dead.

Obviously some of what is visible archaeologically is related to social aspects. So we generally believe that large and lavish tombs, or big mounds, or many grave-goods, mark out people who were high up the social scale. That may well be true; at least, we don't have any better explanation for it. But what about the cases where people are buried in discrete areas of a cemetery, sometimes with indications of genetic affinity, in other words in a family burial area? What about cases with more than one body in the same grave, or of an adult and a child in the same grave (for instance at Trumpington Meadows, Monument I: Evans et al. 2018, 36-49, Figs 2.8-2.14), or the curious double burial from the Jätchenberg bei Westerhausen in Quedlinburg district in SachsenAnhalt (Schmidt 2006 and http://www.lda-lsa.de/landesmuseum_fuer_vorgeschichte/fund_des_monats/2004/mai/, consulted 27 September 2019) (Fig. 2.9)? This burial contains two men, both apparently killed by arrowshots. A recent discussion of the cemetery at Unterhautzenthal, Lower Austria, has discussed the question of female graves containing infants or children, suggesting that it is possible to discern mothers and babies, with the possibility of demonstrating breastfeeding through isotopic changes in bone (Rebay-Salisbury et al. 2018, with one individual showing a clear signal). Such graves have usually been interpreted as mother and child, others as husband and wife, or something similar. The younger the child, perhaps the more likely this is; and there are examples of women with neonates, plausibly interpreted as those who died in childbirth.

Combinations of bodies in graves have also been considered by Frank Falkenstein (2005) in the context of the North Alpine Bronze Age. He found a great deal of variation in the practice, not just infants or children with an adult. For a start, two bodies in a single grave implies simultaneous or near-simultaneous death, which might suggest a suttee-like practice (or intentional killing of a second person on the death of the first, as with the Great Death Pit and other graves at Ur), or perhaps death as a result of an infectious disease. The matter is complicated by the fact that cremation was sometimes used as well as inhumation, so that the relative dates of death are uncertain. In the well-preserved cases, the commonest combination was of a woman with one or two children, occasionally a man with a child. The next most common was of two adults, usually a man and a woman, less commonly two males; up to four individuals can occur in one grave, which might suggest family groupings. Although Falkenstein is at pains to point out that these combinations represent a cross-section of age and sex in society, nevertheless the fact that more than one person can occur in a grave, buried at the same time, suggests unusual (to us) practices or personal or group disasters. 


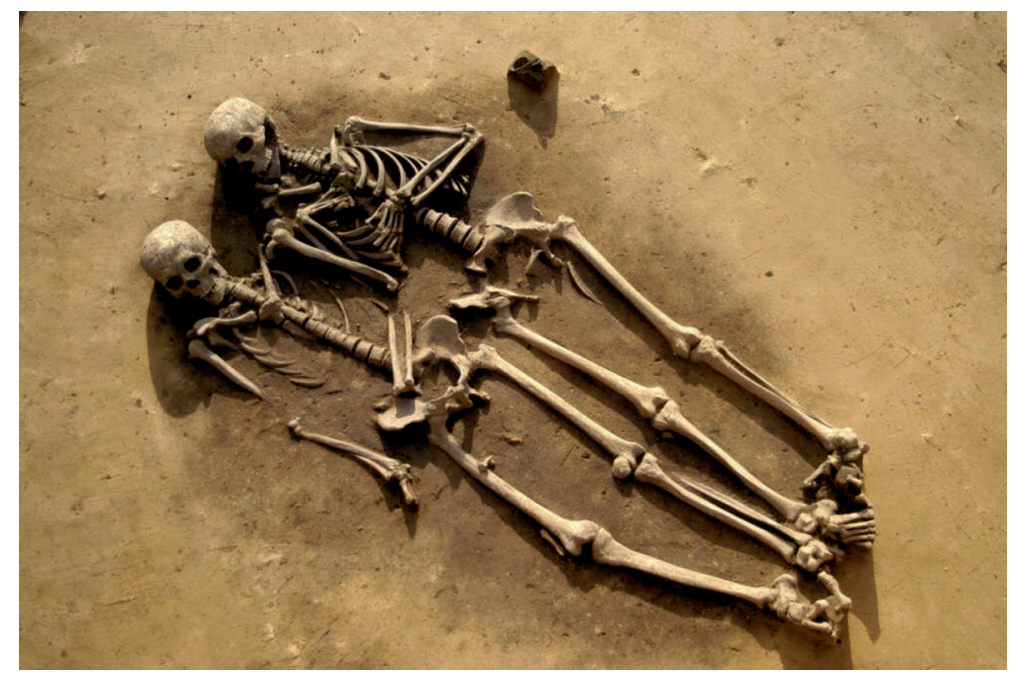

Fig. 2.9: Double burial from the Jätchenberg bei Westerhausen, Quedlinburg district, SachsenAnhalt. Source: Schmidt 2006.

Especially where children are concerned, it is reasonable to see sentiment as playing a big part in the attitude to the dead. Thus toys may be present, as with rattles in Urnfield culture graves (Kaus 1971; Manschus 2012; Pomberger 2016, $46 \mathrm{ff}$; Schmeiduch 2016) (Fig. 2.10), or miniature versions of full-size objects, as with the so-called halberd pendants of the Wessex Culture, which are likely to be children's versions of the real thing (Woodward \& Hunter 2015, $194 \mathrm{ff}$., 232, preferring a different interpretation). Model carts and miniature pots may fall into this category as well.

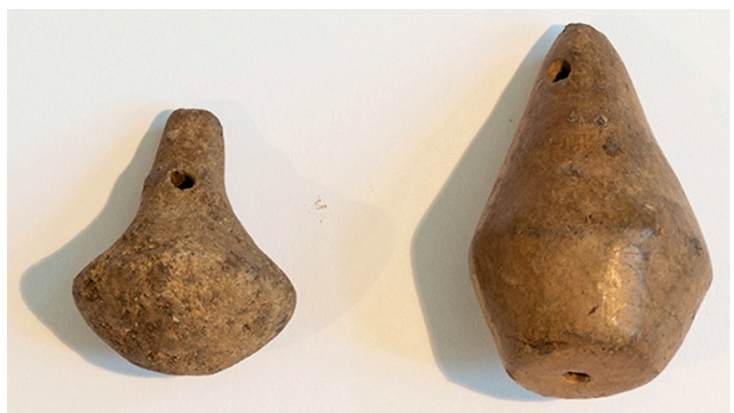

Fig. 2.10: Rattles from Lausitz culture sites in Poland. Photo: Muzeum Ziemi Kępińskiej, Kępno (http://www.muzeumkepno.pl/archeologia.html, consulted 8 October 2019). 
Special treatment of the dead, for whatever reason, has often occupied prehistorians, whether it is unusual placing of the body, re-use of graves, multiple depositions in a single grave, or other effects (e.g. Lauermann 1992). A notable instance is the evidence for special treatment of the body prior to deposition, perhaps in an effort to prevent bodily decay, in other words embalming or mummification. Such effects have been noted in the Western Isles of Scotland (Parker Pearson et al. 2005) and has been considered for the Austrian cemetery of Franzhausen I (Mandl et al. 2018). Usually the disappearance of organic remains prevents any such identification; the same is true in identifying the one-time presence of coffins or biers, a topic I considered in a previous publication (Harding $2000,103 \mathrm{ff}$.). It is highly likely that coffin burial was originally much more common than now appears to be the case.

The fact that funerals were sometimes important and showy occasions can perhaps be glimpsed from the art on the slabs leading to the grave at Kivik in Scania, showing a procession with cart, horses, and people, as well as some unidentified objects (Nordén 1917/1926/1942; Randsborg 1993; Verlaeckt 1993) (Fig. 2.11); this scene has often been compared to those seen on Greek Geometric kraters. Death was a matter for big occasions, especially if the deceased was special in some way.
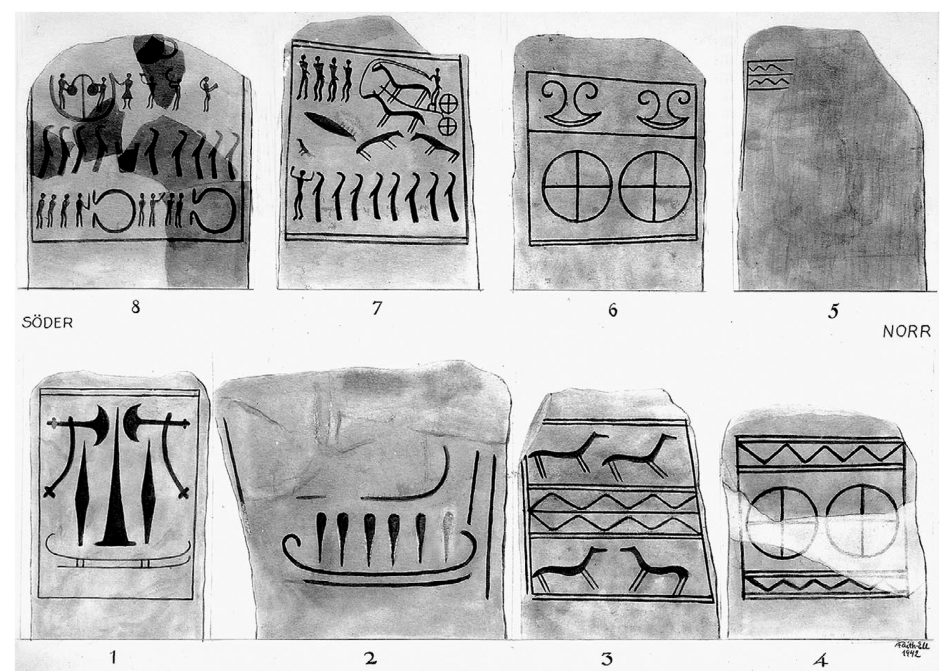

Fig. 2.11: The grave slabs from the massive grave-mound known as Bredarör, Kivik, Scania. Source: Goldhahn 2009. 
All these images and finds tell us something about emotions and feelings, which of course we should expect to find in any society. Can we say anything significant about what people thought would happen to them after death? Here I think that prehistoric archaeologists have to admit defeat. We can suppose that large and visible burial monuments would be a constant reminder of important ancestral figures, maybe even known to the living; but that in itself does not imply any sense of an afterlife. We would have to turn to literate societies, Egypt, Greece, Mesopotamia, to give us some kind of notion of what might be involved with all the dangers of cross-cultural comparison that that would entail. In ancient Egypt, for instance, a lot is known about concepts of the afterlife, and from the things that were put in people's graves we assume that it was believed they would be needed in the hereafter. Whether we can say the same for grave-goods in Europe is impossible to say. But when a grave is filled with personal equipment, and weaponry, such as the so-called Königsgrab at Seddin (Metzner-Nebelsick 1997; May \& Hauptmann 2012), it seems reasonable to suppose so.

In conclusion, the life of people in the Bronze Age was one of mixed hardship and success -hardship because life was uncertain in an age before modern medicine, and because times were evidently uncertain; success, because of extraordinary achievements in technology, artistic endeavour, and control of the environment. It is to some of these achievements that I turn in the following chapters of this book. 